\title{
Medical schools in Brasil: population, economic and historical analysis
}

1. Curso de Graduação em Medicina, Centro de Ciências da Saúde, Universidade Federal de Santa Catarina, Florianópolis, SC, Brasil 2. Departamento de Clínica Médica, Centro de Ciências da Saúde, Universidade Federal de Santa Catarina, Florianópolis, SC, Brasil

\section{SUMMARY}

BACKGROUND: To describe the current distribution and historical evolution of undergraduate courses in medicine in Brasil.

METHODS: Analytical cross-sectional study of secondary data. Through the Ministry of Education, the data of the medical courses were obtained, and through the Brazilian Institute of Geography and Statistics, the population and economic data of the Brazilian states were obtained.

RESULTS: In Brasil, there were 298 medical courses (1,42 courses / million inhabitants) in January 2018, totaling 31,126 vacancies per year, with 9,217 gratuitous vacancies (29.6\%) and 17,963 vacancies in the hinterland (57, 7\%). In Brazilian states, there are positive and statistically significant ( $p$ <.001) correlations of the variables: "vacancies" and "population" (R 0.92); "vacancies" and "gross domestic product" ("GDP") (R 0.83); "percentage of vacancies in the hinterland" and "population in the hinterland" (R 0.71) and "percentage of vacancies in the hinterland" and "GDP" ( $R$ 0.64). There was a negative and statistically significant correlation between "gratuitous vacancy percentage" and "GDP" $(R-0.54, p=0.003)$. More paid courses than gratuitous courses and more courses in the hinterland than in the capitals have been created since 1964, in proportions that have remained similar since then, but in higher numbers since 2002.

CONCLUSIONS: The distribution of medical courses in Brasil correlates with the population and economical production of each state. The expansion of Brazilian medical education, which has been accelerated since 2002, is based mainly on paid courses in the hinterland, in the same pattern since 1964.

KEYWORDS: Medical Education; Medical Schools; Brasil; Population; Gross Domestic Product

\section{INTRODUCTION}

The current concern of Brazilian society regarding medical education, its quality, number of job openings, and access to it by the population is well-known'. There is evidence that the concentration of human resources in health is associated with improved indicators of population health; thus, the evaluation of the distribution of these resources in health systems becomes imperative ${ }^{2.3}$.
Programs to provide and institute medical services in the interior of Brasil date back to the deployment of the Rondon Project, in $1968^{4}$. Since then, various programs encouraging medical work in the countryside, some of them facilitating opening new medical schools, have been implemented, culminating, most recently, in the More Doctors Medical Program (Programa Mais Médicos), launched in $2013^{5}$.

DATE OF SUBMISSION: 29-Jul-2019

DATE OF ACCEPTANCE: 01-Sep-2019

CORRESPONDING AUTHOR: Fabricio Neves

Hospital Universitário, $3^{\circ}$ andar - Rua Maria Flora Pausewang, S/N - Trindade - Florianópolis, SC - Brasil - 88040-900

Tel: 55-48-37219149

E-mail: fabricio.souza.neves@gmail 
Since then, the interest in describing the distribution of medical schools across the Brazilian territory has grown and was embodied by an interinstitutional study initiated in 2014 named "Medical Demography in Brasil"6. The publication, which is currently in its fourth update, presents the distribution of medical schools and their openings in Brasil, per state of the federation and region, according to their "public" or "private" nature and its location in "capitals" or the "hinterland". The data indicated a distribution of vacancies proportional to the population of Brazilian states, with a predominance of private schools (mainly in the South and Southeast regions) and located in hinterland cities ${ }^{6}$.

In order to seek a better understanding of the mechanisms that determine the distribution of medical schools in Brasil, we questioned whether population, economic, or political pressures are its main determinants. To answer this question, we correlated the population and gross domestic product of each state with the number of vacancies in medical schools, as well as its characteristics of gratuitousness and hinterland location. Additionally, we sought to identify the influence of the political alignment of the country in the distribution and characteristics of schools, describing the growth in the number of programs and their behavior of gratuitousness and hinterland location throughout historical periods based on the administrations of the federal government.

\section{METHODS}

This is an analytical cross-sectional study based on secondary data obtained from public databases. We searched the E-MEC website of the Ministry of Education (http://emec.mec.gov.br/) and obtained data from undergraduate medical courses in Brasil by the 31st January 2018. By using the "advanced search" tool, selecting "graduate program", filling it out with the word "medicine", marking the item "exact search", and selecting each Brazilian state, we obtained the following information: name of the institution of higher education, free or paid access, year of beginning, number of annual vacancies, and municipality of location.

The data about the population of each Brazilian state, their Gross Domestic Product (GDP), and population residing in their capitals were obtained by consulting the results of the 2010 demographic census on the Brazilian Institute of Geography and Statistics
(IBGE) website (https://censo2010.ibge.gov.br/). We considered the population residing in the hinterland of each state as the difference between the total state population and the population of the municipality corresponding to the capital of the state.

For the historical analysis, we considered the following periods: Colony and Empire (1808-1889), Old Republic (1890-1929); Vargas Period (1930-1944); Pre-Military Period (1945-1963); Military Period (19641984); Sarney Government (1985-1989); Collor-Itamar (1990-1993); Fernando Henrique (1994-2001); Lula (2002-2009); Dilma (2010-2015), and Temer (2016-2018).

We created a database in Excel ${ }^{\mathrm{TM}} 2010$ (Microsoft ${ }^{\circledR}$ ) and, from it, exported and analyzed the data using Statistica ${ }^{\text {TM }} 13.3\left(\right.$ Tibco $\left.^{\circledR}\right)$.

\section{RESULTS}

Table 1 presents the number of undergraduate medical programs and their annual vacancies in each Brazilian state, in addition to the number of gratuitous vacancies and vacancies in programs in cities located in the hinterland of the states. In Brasil, until January of 2018, there were 298 undergraduate medical programs, totaling 31,126 anual vacancies, 9,217 gratuitous (29.6\% in relation to the national total), and 17,963 located in the hinterland of the country $(57.7 \%$ in relation to the national total).

The Brazilian population, according to the 2010 Demographic Census, is $190,755,799$, of which $145,289,754(76.2 \%)$ reside outside the city corresponding to the capital. The Brazilian GDP in the same year was $\mathrm{R} \$ 3,770,085$ million. The largest population (21,262,199 inhabitants, $21.6 \%$ of the national total) and the largest GDP ( $\mathrm{R} \$ 1,247,596$ million, 33.1\% of the national GDP) are found in the state of São Paulo.

Figure 1a analyzes the correlation between the variables "annual vacancies in medical programs" and the "population" in Brazilian states and the Federal District, with a Spearman coefficient of $0.92(p<0.001)$. Figure $1 \mathrm{~b}$ presents the correlation between the variables "annual vacancies in medical programs" and "GDP" in Brazilian states and the Federal District, with a Spearman coefficient of 0.83 ( $p<0.001)$. Figure $1 c$ correlates the variables "percentage of annual vacancies in medical programs located in the hinterland" and "percentage population residing in the hinterland" in Brazilian states, with a Spearman coefficient of 0.71 $(p<0.001)$. Figure 1d, analyzes the correlation between 
TABLE 1. ANNUAL NUMBER OF VACANCIES IN UNDERGRADUATE MEDICAL SCHOOLS IN BRAZILIAN STATES Number of vacancies in medical schools in Brazilian states (absolute number and percentage in relation to the national total), free vacancies (absolute number and percentage in relation to the state total), vacancies located in the hinterland (absolute number and percentage in relation to the state total), gratuitous vacancies located in the hinterland (absolute number and percentage in relation to the number of vacancies in the hinterland of the state) and gratuitous vacancies located in the capital (absolute number and percentage in relation to the number of vacancies in the state capital)

\begin{tabular}{|c|c|c|c|c|c|c|}
\hline State & $\begin{array}{l}\text { Medical } \\
\text { schools }\end{array}$ & Vacancies & $\begin{array}{l}\text { Gratuitous } \\
\text { Vacancies }\end{array}$ & $\begin{array}{l}\text { Vacancies in the } \\
\text { hinterland }\end{array}$ & $\begin{array}{l}\text { Gratuitous vacancies } \\
\text { in the hinterland }\end{array}$ & $\begin{array}{l}\text { Gratuitous vacan- } \\
\text { cies in the capital }\end{array}$ \\
\hline SP & 55 & 6,279 (20.1\%) & $756(12.0 \%)$ & 4,465 (71.1\%) & $575(12.9 \%)$ & $181(10.0 \%)$ \\
\hline$M G$ & 43 & $4,475(14.3 \%)$ & 1,405 (31.4\%) & $3,213(71.8 \%)$ & 1,085 (33.8\%) & $320(25.4 \%)$ \\
\hline $\mathrm{RJ}$ & 20 & $2,821(9.0 \%)$ & $694(24.6 \%)$ & 1,655 (58.7\%) & $240(14.5 \%)$ & $454(38.9 \%)$ \\
\hline PR & 19 & 1,894 (6.0\%) & $490(25.9 \%)$ & 1,135 (59.9\%) & $300(26.4 \%)$ & $190(25.0 \%)$ \\
\hline $\mathrm{BA}$ & 19 & $1,798(5.7 \%)$ & $673(37.4 \%)$ & $838(46.6 \%)$ & $453(54.1 \%)$ & $220(22.9 \%)$ \\
\hline RS & 19 & $1,762(5.6 \%)$ & $680(38.6 \%)$ & 1,402 (79.6\%) & $440(31.4 \%)$ & $240(66.7 \%)$ \\
\hline GO & 12 & $12.82(4.1 \%)$ & $220(17.2 \%)$ & $1,048(81.7 \%)$ & $110(10.5 \%)$ & $110(47.0 \%)$ \\
\hline $\mathrm{PE}$ & 10 & $1,110(3.5 \%)$ & $510(45.9 \%)$ & $340(30.6 \%)$ & $220(64.7 \%)$ & $290(37.7 \%)$ \\
\hline CE & 8 & $1,036(3.2 \%)$ & $400(38.6 \%)$ & $400(38.5 \%)$ & $160(40.0 \%)$ & $240(37.7 \%)$ \\
\hline PB & 9 & $1,026(3.2 \%)$ & $265(25.8 \%)$ & $544(53.0 \%)$ & $120(22.1 \%)$ & $145(30.1 \%)$ \\
\hline SC & 12 & $910(2.9 \%)$ & $140(15.5 \%)$ & $810(89.0 \%)$ & $40(4.9 \%)$ & $100(100 \%)$ \\
\hline PA & 6 & $610(1.9 \%)$ & $310(50.8 \%)$ & $60(9.8 \%)$ & $60(100 \%)$ & $250(45.5 \%)$ \\
\hline $\mathrm{PI}$ & 7 & $601(1.9 \%)$ & $240(39.9 \%)$ & $190(31.6 \%)$ & $110(57.9 \%)$ & $130(31.6 \%)$ \\
\hline TO & 6 & $600(1.9 \%)$ & $160(26.7 \%)$ & $420(70.0 \%)$ & $100(23.8 \%)$ & $60(33.3 \%)$ \\
\hline AM & 5 & $585(1.8 \%)$ & $290(49.6 \%)$ & $48(9.2 \%)$ & $48(100 \%)$ & $242(45.1 \%)$ \\
\hline MA & 6 & $579(1.8 \%)$ & $330(57.0 \%)$ & $330(57 \%)$ & $230(69.7 \%)$ & $100(40.2 \%)$ \\
\hline ES & 5 & $570(1.8 \%)$ & $80(14.0 \%)$ & $270(47.4 \%)$ & $0(0.0 \%)$ & $80(26.7 \%)$ \\
\hline $\mathrm{AL}$ & 5 & $495(1.5 \%)$ & $210(42.4 \%)$ & $60(12.1 \%)$ & $60(100 \%)$ & $150(34.5 \%)$ \\
\hline DF & 5 & $476(1.5 \%)$ & $156(32.8 \%)$ & - & - & - \\
\hline RN & 5 & $472(1.5 \%)$ & $280(59.3 \%)$ & $180(38.1 \%)$ & $180(100 \%)$ & $100(34.2 \%)$ \\
\hline MT & 6 & $431(1.3 \%)$ & $240(55.7 \%)$ & $280(65 \%)$ & $160(57.1 \%)$ & $80(53.0 \%)$ \\
\hline MS & 5 & $388(1.2 \%)$ & $268(69.1 \%)$ & $140(36.1 \%)$ & $140(100 \%)$ & $128(51.6 \%)$ \\
\hline ORA & 4 & $325(1.0 \%)$ & $40(12.3 \%)$ & $75(23.1 \%)$ & $0(0.0 \%)$ & $40(16.0 \%)$ \\
\hline SE & 3 & $300(1.0 \%)$ & $160(53.3 \%)$ & $60(20.0 \%)$ & $60(100 \%)$ & $100(41.7 \%)$ \\
\hline$A C$ & 2 & $161(0.5 \%)$ & $80(49.7 \%)$ & $0(0.0 \%)$ & - & $80(49.7 \%)$ \\
\hline $\mathrm{RR}$ & 1 & $80(0.2 \%)$ & $80(100 \%)$ & $0(0.0 \%)$ & - & $80(100 \%)$ \\
\hline$A P$ & 1 & $60(0.2 \%)$ & $60(100 \%)$ & $0(0.0 \%)$ & - & $60(100 \%)$ \\
\hline Brasil & 298 & 31,126 & $9,217(29.6 \%)^{*}$ & $17,953.001(57.7 \%)^{\star}$ & $4,891(27.2 \%)^{\star}$ & $4,170(32.9 \%)^{*}$ \\
\hline
\end{tabular}

Source: E-mec, accessed on the 31st January 2018. ${ }^{*}$ Percentage in relation to the national data

TABLE 2. IN EACH PERIOD OF BRAZILIAN HISTORY: UNDERGRADUATE MEDICAL SCHOOLS CREATED IN BRASIL

Created medical schools (absolute number and percentage in relation to the current total), gratuitous medical schools created (absolute number and percentage in relation to the total at the time), medical schools created in the hinterland (outside of municipality capitals, absolute number and percentage in relation to the total at the time), Brazilian population and schools/million inhabitants ratio

\begin{tabular}{|c|c|c|c|c|c|}
\hline $\begin{array}{l}\text { Historical } \\
\text { period }\end{array}$ & $\begin{array}{l}\text { Created medi- } \\
\text { cal schools }\end{array}$ & $\begin{array}{l}\text { Gratuitous medical schools } \\
\text { created in the period }\end{array}$ & $\begin{array}{l}\text { Medical Schools created in } \\
\text { the hinterland in the period }\end{array}$ & $\begin{array}{l}\text { Brazilian popula- } \\
\text { tion }^{*}\end{array}$ & $\begin{array}{l}\text { Medical school/mil- } \\
\text { lion inhabitants }\end{array}$ \\
\hline 1808-1889 & $2(0.7 \%)$ & $2(100 \%)$ & $0(0.0 \%)$ & $14,333,915$ & 0.14 \\
\hline 1890-1929 & $8(2.7 \%)$ & $8(100 \%)$ & $1(12.5 \%)$ & $30,635,605$ & 0.33 \\
\hline 1930-1944 & $2(0.7 \%)$ & $2(100 \%)$ & $0(0.0 \%)$ & $41,236,315$ & 0.29 \\
\hline 1945-1963 & $25(8.4 \%)$ & $19(76.0 \%)$ & $9(35.7 \%)$ & $51,944,397$ & 0.71 \\
\hline 1964-1984 & $36(12.1 \%)$ & $13(36.1 \%)$ & $26(72.2 \%)$ & $121,150,573$ & 0.60 \\
\hline 1985-1989 & $3(1.0 \%)$ & $1(33.3 \%)$ & $3(100 \%)$ & $146,917,459$ & 0.52 \\
\hline 1990-1993 & $1(0.3 \%)$ & $0(0.0 \%)$ & $1(100 \%)$ & $146,917,459$ & 0.52 \\
\hline 1994-2001 & $30(10.1 \%)$ & $10(33.3 \%)$ & $20(66.7 \%)$ & $169,590,693$ & 0.63 \\
\hline 2002-2009 & $69(23.2 \%)$ & $17(24.6 \%)$ & $42(60.9 \%)$ & $190,755,799$ & 0.92 \\
\hline 2010-2015 & $85(28.5 \%)$ & $31(36.5 \%)$ & $66(77.6 \%)$ & $204,450,649 \dagger$ & 1.28 \\
\hline $2016-2018$ & $37(12.4 \%)$ & $9(24.3 \%)$ & $34(91.9 \%)$ & $209,240,607 \ddagger$ & 1.42 \\
\hline Total & 298 & 112 & 203 & & \\
\hline
\end{tabular}

Sources: E-mec, acessed on the 31st January 2018. * IBGE, population estimates, 1890, 1920, 1940, 1960, 1980, 1991, 2000, and 2010.† IBGE, population estimate, 2015. ‡ IBGE population estimate, 2018. 
the variables "percentage of annual vacancies in medical programs located in the hinterland" and the "GDP" in Brazilian states, with a Spearman coefficient of 0.64 $(p<0.001)$. There are positive and statistically significant correlations between these variables. Figure 1e considers the correlation between the variables "percentage of gratuitous vacancies in medical schools" and "GDP" in Brazilian states and the Federal District, with a Spearman coefficient of $-0.54(p=0.003)$. Note that there is a negative and statistically significant correlation between the variables. There was no significant correlation between the percentage of gratuitous vacancies in the hinterland and the percentage of the population residing in the hinterland or the GDP of the states.

Table 2 presents the number and characteristics of the undergraduate medical programs created in each period of Brazilian history, correlated to the Brazilian population growth. On the percentage of gratuitousness, the table shows a single inflection point: after 1964 , the proportion of gratuitous courses is significantly lower than in the previous period $(p<0.001$, Fisher's exact test). The same year marks the inflection point for the percentage of hinterland location: after 1964, the proportion of courses in the hinterland is significantly higher than in the previous period ( $<<0.001$, Fisher's exact test). These percentages have not changed significantly since then. As for the quantitative aspect, the year that marks a significant change is 2002: between 1964 and 2001, the course/million inhabitants ratio remained stable between 0.52 and 0.63. After 2002, it increased gradually, between 0.92 and 1.42. The difference between the averages of the index in the two periods (1964-2001 vs. 2002-2018) is significant ( $\mathrm{p}=0.04, t$-test).

\section{DISCUSSION}

In the present study, we observed correlations between the distribution of vacancies in medical schools in Brazilian states and their populations and economic production. The data correlation does not allow us to infer cause and effect relationships, because the opening of a medical school in a municipality, especially in medium-sized ones, can attract people and business to the region just as much as the population growth and economic development of a municipality can create a need and the conditions necessary for the opening of a medical school. Both relationships can be true and complementary.
There are also correlations between the percentage of the population residing in the hinterland of each state, the state's GDP, and the percentage of vacancies in medical schools in the hinterland. In the same way, we can consider a possible two-way relationship of cause and effect: a more populous and productive hinterland allows the emergence of medical schools, which in turn enriches the social and economic life of cities in the hinterland.

We also found a significant negative correlation between the state GDP and the percentage of gratuitous vacancies in medical schools. This finding reinforces the link between the growth of a region and the emergence of private medical schools. Thus, we can deduce that the expansion of medical education in Brasil has occurred at a more accelerated pace where there is more economical and population growth and that the private initiative is the main force behind this expansion.

The analysis of historical data (Table 2) shows that the proportion of gratuitous medical schools located in the capitals was predominant until 1964. From then on, paid programs and located in the hinterland of states became more predominant. Since 1964, the proportion of gratuitous medical schools created in each period has varied between $24 \%$ and $36 \%$, with no significant difference between any of the subsequent governments, and the hinterland location has varied between $62 \%$ and $91 \%$. The trend toward the expansion of medical education by means of paid programs seems to have started even before that, from the end of the Getúlio Vargas administration', but it was certainly consolidated during the military period and so remained ever since. In quantitative terms, it should be noted that the medical school/million inhabitants ratio, which remained stable between 0.52 and 0.63 from 1964 until 2001 (number of medical schools followed the population growth), jumped to 0.92 in the period from 2002 to 2009 and increased progressively until 2018, reaching 1.42 medical schools per million inhabitants (number of medical schools growing faster than the population).

We cannot say that all medical education located in the hinterland is predominantly offered through paid schools because the percentage of gratuitous vacancies in the hinterland of the states (27.2\%) is not significantly different from the national average (29.6\%), nor from the percentage of gratuitous vacancies in the state capitals (32.9\%). The correlation between the percentage of gratuitous vacancies in state hinterlands 


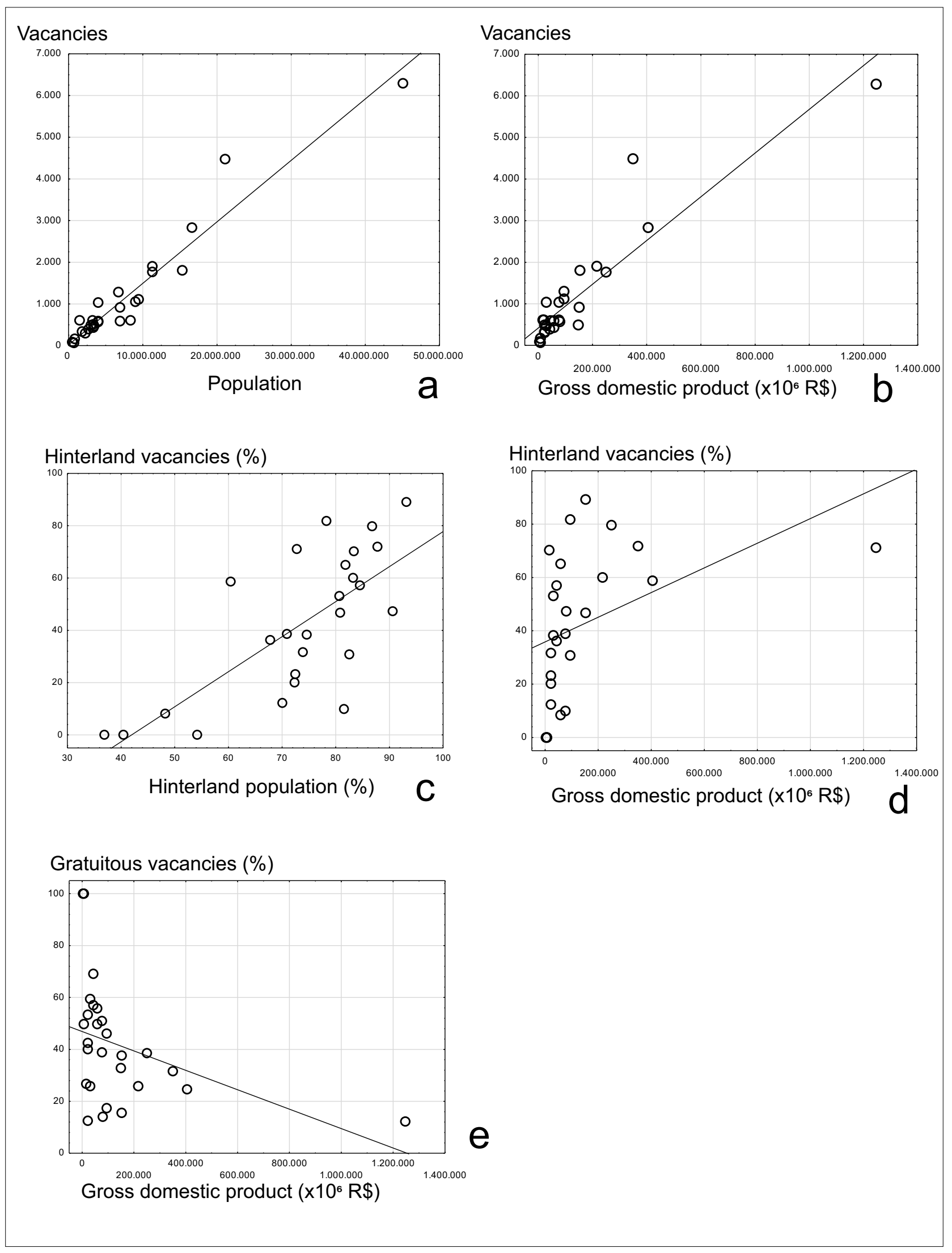

FIGURA 1. CORRELATIONS BETWEEN VACANCIES IN MEDICAL SCHOOLS AND POPULATION OR GROSS DOMESTIC PRODUCT IN BRAZILIAN STATES. 
with the GDP or with the percentage of the population residing in the hinterland was not significant. What can be observed is the great variability between states in the distribution of gratuitous vacancies between the capital and the hinterland: some maintain a similar proportion between capital and hinterland (SP, 10.0\% and $12.9 \%$; CE, $37.7 \%$, and $40.0 \%$; MT, $53.0 \%$ and $57.1 \%)$; others have a greater proportion of gratuitous vacancies in the capitals (SC, $100 \%$ and $4.9 \%$; RJ, $38.9 \%$ and $14.5 \%$; RS, $66.7 \%$ and $31.4 \%$ ); while others have a lower proportion in the capitals (BA, $22.9 \%$ and $54.1 \%$; 37.7\%, and $64.7 \%$ PA, $45.5 \%$; and 100\%). Three states have $100 \%$ of vacancies in the capitals gratuitous (SC, RR, and AP), and six states (PA, AM, AL, RN, MS, and SE) have $100 \%$ of their vacancies in the hinterland gratuitous. Therefore, in some states, the spread of medical schools in the hinterland occurred predominantly through paid schools, while in others, through gratuitous schools, whereas in most states, both cases occurred.

The scientific literature gives scant attention to the number and characteristics of medical schools worldwide and in Brasil. Particularly, there are no data on the number of vacancies in medical schools, only about the number of schools. For this reason, we can compare the data on the number of medical schools (and not vacancies) in Brasil with global data. It is important to highlight that this comparison has less reliability than that based on the number of vacancies: in some countries, medical schools offer a large number of annual vacancies (and, therefore, there is a small number of medical schools in the country), while in Brasil we have an average of around 100 annual vacancies per medical school.

In Brasil, there are currently 1.42 medical schools per million inhabitants. A study from 2014 found 0.20 medical schools per million inhabitants in the African continent; 0.81 in the Americas; 0.28 in Asia; 0.55 in Europe; and 0.81 in Oceania ${ }^{7}$. These data place Brasil above the global average and the average of the American continent in terms of the number of medical schools in relation to the population; we found that such accelerated growth took place from 2002.

In 2002, Eckhert ${ }^{8}$ traced the number and distribution of medical schools using publicly available information from the yearbook of the World Health Organization (WHO): at that time, three countries had more than 100 medical schools: China (150), India (144), and the USA (144). In 2007, Boulet et al. ${ }^{9}$ reported that over a third of medical schools were in four countries: India (219), the USA (147), China (130), and Brasil(84). In 2014, Duvivier et al. ${ }^{7}$ identified the countries with the highest number of medical schools: India (304), Brasil(182), the USA (173), China (147), and Pakistan (86). From a perspective of the production of human resources, such concentration suggests that the distribution of medical schools is determined not only by the population need ${ }^{7.9}$.

The qualitative characteristics of each school, such as their "free" or "paid" nature, could be more directly influenced by political factors ${ }^{1,10,11}$. Our study detected a single change in the proportion of "free" to "paid" programs over the analyzed historical periods, in which the proportion was reversed, with the predominance of paid schools after 1964. Since then, there has been no significant change in this pattern in any subsequent period. Regarding the investigation of the population access routes to medical education, this study has the limitation of not presenting data on public funding for access to paid programs. Since 2001, the Brazilian Ministry of Education offered the Student Financing Fund (FIES) program, which may indicate that, although the driving force behind the expansion of medical education from the second half of the 20th did not come from public investments, from the 21st century, public resources were invested in education differently (offering financial credit for low-income students to attend paid institutions) ${ }^{12}$. In addition, other factors may be listed as facilitators of access to higher education: when a school is established in hinterland cities, even "paid" ones, students can save on expenses regarding housing or moving to another city, all of which would be necessary in order to have access to a "gratuitous" institution in a more distant capital with a higher cost of living, for example.

Finally, it is worth emphasizing that our study did not explored the correlation between the distribution of medical schools and subsequent city of work of graduated doctors. The factors that influence this process are complex and include multiple variables of economic and social nature (local working conditions, regional conditions of diagnostic and therapeutic support, and the educational possibilities for the professionals and their relatives).

Despite the limitations, studies like this provide valuable data for a more thorough evaluation of the scenario of medical schools in the country and subsidize the development of strategies that promote a better distribution of physicians across the national territory. 


\section{CONCLUSION}

This study showed that Brasil had, in January of 2018, 298 medical schools, totaling 31,126 annual vacancies, of which the minority were gratuitous $(29.6 \%$ of the vacancies), and most were located in the hinterland of the country ( $57.7 \%$ of the vacancies). The distribution of vacancies across Brazilian states is directly correlated to the population and Gross Domestic Product of each state, and the proportion of vacancies in the hinterland of Brazilian states also correlates directly to the proportion of the population residing in the hinterland and the Gross Domestic Product of each state. However, the proportion of gratuitous vacancies in medical programs is inversely correlated to the Gross Domestic Product of each state. We also found that the expansion in number of Brazilian medical schools grew more than the population from 2002, predominantly due to paid schools located in the hinterland of states, a characteristic that has remained unchanged since 1964.

\section{Author Contributions}

Silva ACV: study design, data collection and analysis, drafting of the manuscript, and approval of the final version. Godoi DF: data interpretation, drafting and critical review of the manuscript, and approval of the final version. Neves FS: study design, data analysis and interpretation, drafting and critical review of the manuscript, and approval of the final version.

\section{RESUMO}

OBJETIVO: Descrever a distribuição e evolução histórica das vagas em cursos de graduação em medicina no Brasil.

MÉTODOs: Estudo transversal analítico de dados secundários. No Ministério da Educação obtiveram-se dados dos cursos de medicina e no Instituto Brasileiro de Geografia e Estatística foram obtidos dados populacionais e econômicos dos estados.

RESULTADOS: Havia no Brasil, até janeiro de 2018, 298 cursos de medicina (1,42 curso/milhão de habitantes), totalizando 31.126 vagas anuais, com 9.217 vagas gratuitas (29,6\%) e 17.963 vagas no interior do País (57,7\%). Nos estados há correlações positivas e significativas ( $p<0,001)$ das variáveis: "vagas em medicina" e "população" ( $R$ 0,92); "vagas em medicina" e "produto interno bruto" ("PIB") (R 0,83); "percentual de vagas em medicina no interior" e "população no interior" ( 0,71$)$ e "percentual de vagas em medicina no interior" e "PIB" $(R 0,64)$. Há correlação negativa e significativa entre "percentual de vagas gratuitas" e "PIB" ( $R-0,54, p=0,003)$. Passaram a ser criados mais cursos pagos do que gratuitos e mais cursos no interior do que nas capitais a partir de 1964 ( $p<0,001$ ), e a relação curso/milhão de habitantes aumentou a partir de $2002(p<0,001)$.

CONCLUSÕES: A distribuição de vagas em cursos de medicina no Brasil correlaciona-se à população e à produção econômica de cada estado. A expansão do ensino médico brasileiro, acelerada além do crescimento populacional a partir de 2002, é baseada principalmente em cursos pagos no interior dos estados brasileiros, característica inalterada desde 1964.

PAlaVRAS-ChaVe: Educação médica. Faculdades de medicina. Brasil. População. Produto Interno Bruto.

\section{REFERENCES}

1. Amaral |L. Duzentos anos de ensino médico no Brasil [Tese de doutorado]. Rio de Janeiro: Universidade do Estado do Rio de Janeiro, Instituto de Medicina Social; 2007

2. Anand S, Bärnighausen T. Human resources and health outcomes: cross-country econometric study. Lancet. 2004;364(9445):1603-9.

3. Hopkins Tanne J. US patients live longer in areas with more primary care doctors, study finds. BMJ. 2019;364:1804.

4. Carvalho MS, Sousa MF. Como o Brasil tem enfrentado o tema provimento de médicos? Interface. 2013;17(47):913-26.

5. BRASIL. Presidência da República. Lei No. 12.871, de 22 de outubro de 2013. Institui o Programa Mais Médicos, altera as Leis No. 8.745, de 9 de dezembro de 1993 e No. 6.932, de 7 de julho de 1981, e dá outras providências. Brasília: Diário Oficial da União, 23 out. 2013.

6. Scheffer M, Cassenote A, Guilloux AGA, Biancarelli A, Miotto BA, Mainardi GM. Demografia médica no Brasil 2018. São Paulo: Departamento de Medicina Preventiva da Faculdade de Medicina da Universidade de São
Paulo, Conselho Federal de Medicina, Conselho Regional de Medicina do Estado de São Paulo; 2018

7. Duvivier RJ, Boulet JR, Opalek A, van Zanten M, Norcini J. Overview of the world's medical schools: an update. Med Educ. 2014;48(9):860-9.

8. Eckhert NL. The global pipeline: too narrow, too wide or just right? Med Educ. 2002;36(7):606-13.

9. Boulet |, Bede C, McKinley D, Norcini |. An overview of the world's medical schools. Med Teach. 2007;29(1):20-6

10. Feuerwerker L. Além do discurso de mudança na educação médica: processos e resultados. Rio de Janeiro: Hucitec; 2002.

11. Dantas AB. Egressos de medicina no Pará [Dissertação de Mestrado]. Belém: Universidade Federal do Pará, Centro de Educação, Mestrado em Educação; 2006.

12. Silva AM, Santos BCS. Eficácia de políticas de acesso ao ensino superior privado na contenção da evasão. Avaliação. 2017;22(3):741-57. 